Vol.3 No.2 Hal. $37-43$

September 2020
BEST JOURNAL

(Biology Education,Science \& Technolog̉y)

Fakultas Keguruan dan IImu Pendidikan
ISSN (Print) : $2614-8064$

ISSN (Online): $2654-4652$

\title{
Vegetable Oil Sebagai Alternatif Pengganti Immersion Oil
}

\author{
Ria Ika Maharani ${ }^{(1)}$, Dewi Mustikaningtyas ${ }^{(2)}$, Kartika Widyaningrum ${ }^{(3)}$ \\ Laboratorium Biologi Jurusan Biologi FMIPA UNNES
}

Ria.ika@mail.unnes.ac.id ${ }^{(1)}$, dewi_mustikaningtyas@mail.unnes.ac.id ${ }^{(2)}$, kartikawidya@mail.unnes.ac.id $^{(3)}$

\begin{abstract}
ABSTRAK
Menemukan alternatif pengganti immersion oil sebagai media dalam pengamatan preparat bakteri dengan perbesar kuat mikroskop perlu dilakukan. Prinsip yang digunakan adalah nilai indek bias minyak yang dipilih harus masuk dalam rentang yang dibutuhkan. Penelitian ini dirancang dengan tujuan mendapatkan alternatif pengganti immersion oil dengan vegetable oil. Metode yang dipakai dalam penelitian ini adalah penelitian eksperimental dengan berfokus pada ketajaman dan kontras gambar hasil pengamatan. Analisis data dengan uji normalitas menggunakan saphiro wilh test spss, dilajutkan uji kruskal wallis test spps. Hasil penelitian ini menunjukan bahwa vegetable oil dapat digunakan sebagai alternatif pengganti immersion oil dengan perbedaan hasil pengamatan tidak berbeda secara signifikan.
\end{abstract}

Kata Kunci : immersion oil, vegetable oil, mikroskop, preparat bakteri

\begin{abstract}
Finding alternative substitutes for immersion oil as a medium in observing bacterial preparations with a stronger microscope needs to be done The principle used is the refractive index value of the selected oil is still within the required range. This research was designed with the aim of getting an alternative to immersion oil with vegetable oil. The method used in this study is an experimental study focusing on the sharpness and contrast of the images observed. Data analysis with normality test using saphiro wilh test spss, continued by kruskal wallis test spps test. The results of this study indicate that vegetable oil can be used as an alternative to immersion oil with different observations not significantly different.
\end{abstract}

Keywords : immersion oil, vegetable oil, microscope, bacterial preparation. 
Maharani RI, Mustikaningtyas D, Widyaningrum K : Vegetable Oil Sebagai Alternatif Pengganti Immersion Oil

\section{PENDAhUluan}

\section{Latar Belakang}

Penggunaan perbesaran kuat dengan lensa obyektif 100x memerlukan tambahan minyak sebagai media dalam peningkatan resolusi dan bukaan numerik (NA). Fungsi minyak disini untuk mengurangi jumlah refraksi dan pantulan cahaya dari obyek, serta meningkatkan kemampuan dalam menangkap cahaya yang menyimpan. Jenis minyak yang digunakan memiliki indeks bias mendekati indeks bias kaca obyek, sehingga tidak ada penyimpangan cahaya saat menembusnya. Minyak yang digunakan secara umum di laboratorium adalah immersion oil dengan indeks bias 1.51, sedangkan indek bias kaca 1.485-1.755. Immersion oli yang sekarang ini banyak diproduksi dan beredar memang telah terstandarisasi untuk memastikan bahwa mereka tidak merusak lensa atau tidak berubah warna seiring bertambahnya usia (Wilson, 2017). Meskipun begitu terdapat kekurangan dari immersion oil berkerja optimal pada suhu $23{ }^{\circ} \mathrm{C}$ dan mengalami perubahan indeks bias 0,0004 dengan adanya perubahan suhu $1{ }^{\circ} \mathrm{C}$ (Cargille, 2008). Dan immersion oil telah diketahui memiliki dampak negatif untuk kulit (Christophe et.al, 2017) dan berbahaya bagi lingkungan air dalam jangka panjang (U.S. National Library Of Medicine. 2020). Harga perolehan immersion oil cukup mahal, karena harus menerapkan aturan ketat berdasarkan ISO (Sacher, R. 2000). Vegetable oil merupakan kekayaan hayati yang perlu dimanfaatkan dan dikonservasikan. Penelitian mengenai beberapa jenis vegetable oil dapat digunakan sebagai pengganti immersion oil yaitu coconut oil (Balba et.al, 2018) dan castor oil (Victor et.al, 2005). Obyek yang diamati dari penggunaan vegetable oil diatas berupa histologi dan kromosom, belum ada penggunaan untuk obyek berupa bakteri. Selain dua minyak diatas masih ada olive oil yang memiliki indek bias 1.44-1.47, masih berada direntang kedua minyak terdahulu (International Gem Society. 2017). Di laboratorium biologi FMIPA UNNES penggunaan immersion oil paling banyak pada kegiatan pengamatan bakteri dan belum pernah dicoba untuk memanfaatkan minyak lain. Pemilihan vegetable oil sebagai pengganti dikarena beberapa pertimbangan yaitu memiliki indeks bias yang masih masuk dalam syarat sebagai minyak pengamatan, panasnya stabil, tidak mudah teroksidasi, aman bagi pengguna, murah bila dibandingkan dengan immersion oil (Adeniyi et.al, 2015), dan yang paling utama sebagai sarana konservasi dan pemanfaatan keanekaragaman hayati...

\section{Perumusan Masalah}

Masalah yang dapat dirumuskan dari latar belakang tersebut adalah mendapatkan alternatif pengganti immersion oil yang aman, murah dan berkontribusi dalam konservasi hayati.

\section{Tujuan Penelitian}

Tujuan yang ingin dicapai yaitu mengidentifikasi kemungkinan vegetable oil sebagai alternatif pengganti immersion oil dari segi kualitas gambar berdasarkan ketajaman dan kontras dan untuk menentukan apakah ada perbedaan yang signifikan antara gambar yang dihasilkan menggunakan immersion oil dan vegetable oil

\section{Manfaat Penelitian}

Manfaat yang akan didapat dari penelitian ini adalah mendapatkan bahan alternatif yang mudah untuk diaplikasikan dalam kegiatan di laboratorium serta memenuhi dari segi ekonomi, keamanan dan kontribusi terhadap konservasi keanekaragaman hayati

\section{METODE PENELITIAN}

Metode yang dipakai dalam penelitian ini adalah penelitian eksperimental dengan berfokus pada ketajaman dan kontras gambar hasil pengamatan. Teknik pengambilan data menggunakan metode skor 1-3 dengan indikator pengamatan dari ketajaman dan kontras 
gambar. Sampel pengamat diambil berdasarkan purposive sampling, sebagai bahan pertimbangan penentu sampel adalah pengguna yang paham dan terbiasa dengan pengamatan bakteri perbesaran kuat. Jadi sampel yang dipilih adalah peneliti terkait dan mahasiswa yang telah mengambil mata praktikum mikrobiologi. Data yang diperoleh digunakan sebagai data mentah kedalam uji normalitas dalam statistik spss. Analisis dengan uji normalitas menggunakan saphiro wilk test spss, dilanjutkan dengan uji kruskal wallis test spps.

\section{HASIL DAN PEMBAHASAN}

Pengamatan preparat bakteri pada saat dilakukan praktikum mata mikrobiologi selama ini tidak lepas dari penggunaan immersion oil, sebagai pengurang jumlah refraksi, pantulan cahaya dari obyek dan menaikkan kemapuan menangkap cahaya yang menyimpang. Pemilihan minyak sebagai media perendaman menjadi hal penting untuk mendapatkan indek bias yang tepat. Pengaruhnya ada pada penurunan kualitas dan kontras gambar secara signifikan dan menjadi salah satu penyimpangan yang paling umum dalam mikroskop cahaya fluoresensi.Vegetable oil yang dipakai adalah EVCO, EVOO dan castor dengan indek bias 1.43-1.46, 1.44-1.47 dan 1.47-1.48 (Davidson, Michael W. 2017). Ketiga minyak ini memiliki indek bias yang masih berada dalam rentang indek bias kaca yaitu 1.485-1.755. Fisik dari ketiga minyak ini memiliki warna jernih hingga kekuningan. Kelebihan dari vegetable oil dapat diperbaharui/terbarukan/renewable, sustainable, tidak beracun, dapat diurai kembali/biodegradable, dan ramah lingkungan. Indeks bias yang dihasilkan dalam pengamatan preparat dengan minyak dipengaruhi oleh suhu, ketebalan gelas penutup preparat, ketebalan dari preparat, indek bias minyak yang digunakan, dan panjang gelombang eksitasi (GE Healthcare Bio-Sciences Corp. 2017). Variasi suhu dapat mempengaruhi indeks bias minyak untuk setiap kenaikan suhu $3{ }^{\circ} \mathrm{C}$, indek bias naik sebanyak 0,002. Hal ini akan sangat berpengaruh ketika penggunaan mikroskop dalam jangka waktu lama, karena sumber cahaya yang digunakan akan meningkatkan suhu minyak yang dilewatinya. Penggunaan gelas penutup pada preparat yang diamati memberikan pengaruh terhadap indek bias yang diteruskan, bila ketebalan meningkat $1 \mu \mathrm{m}$ saja akan dapat meningkatkan indek bias 0,010. Sehingga perlu diperhatikan dalam pemilihan gelas penutup yang ideal digunakan memiliki ketebalan $170 \mu \mathrm{m}$. Pengaruh yang diberikan ketebalan preparat terhadap indek bias cukup besar pula, yaitu untuk setiap kenaikan ketebalan $5 \mu \mathrm{m}$ membuat indek bias bertambah 0,002. Ini menyebabkan pada proses pembuatan preparat hingga pewarnaan menjadi bagian yang vital. Pewarnaan preparat bakteri menggunakan bantuan alat STAFAN untuk menghasilkan hasil lebih cepat dan dalam jumlah lebih dari satu (Maharani dkk, 2019). Hasil pembuatan preparat bakteri sebagai preparat pengamatan dalam penelitian (gambar 2). Faktor pemilihan minyak dengan indek bias tertentu memberikan efek yang besar, sebab dengan minyak yang tepat dapat dihasilkan hasil pengamatan optimal. Selain itu pula adanya pengaruh dari panjang gelombang eksitasi dari sumber cahaya yang dihasilkan, pemilihan sumber cahaya pada mikroskop berpengaruh terhadap hasil yang optimal pada pangamatan. 
Maharani RI, Mustikaningtyas D, Widyaningrum K : Vegetable Oil Sebagai Alternatif Pengganti Immersion Oil

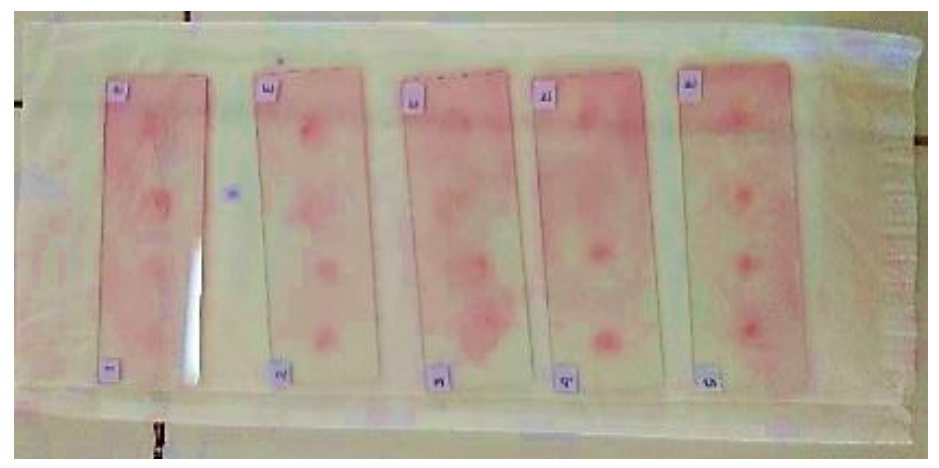

Gambar 2. Preparat bakteri E.Coli

Pengamatan yang dilakukan pada preparat bakteri E. Coli dengan menggunakan keempat minyak disajikan dalam tabel 1. Dari pengamatan tidak memberikan perbedaan signifikan hasil pengamatan, preparat dapat teramati dengan ketajaman dan kontras yang hampir sama. Tabel 1. Perbandingan pengamatan menggunakan keempat minyak dengan preparat E.Coli

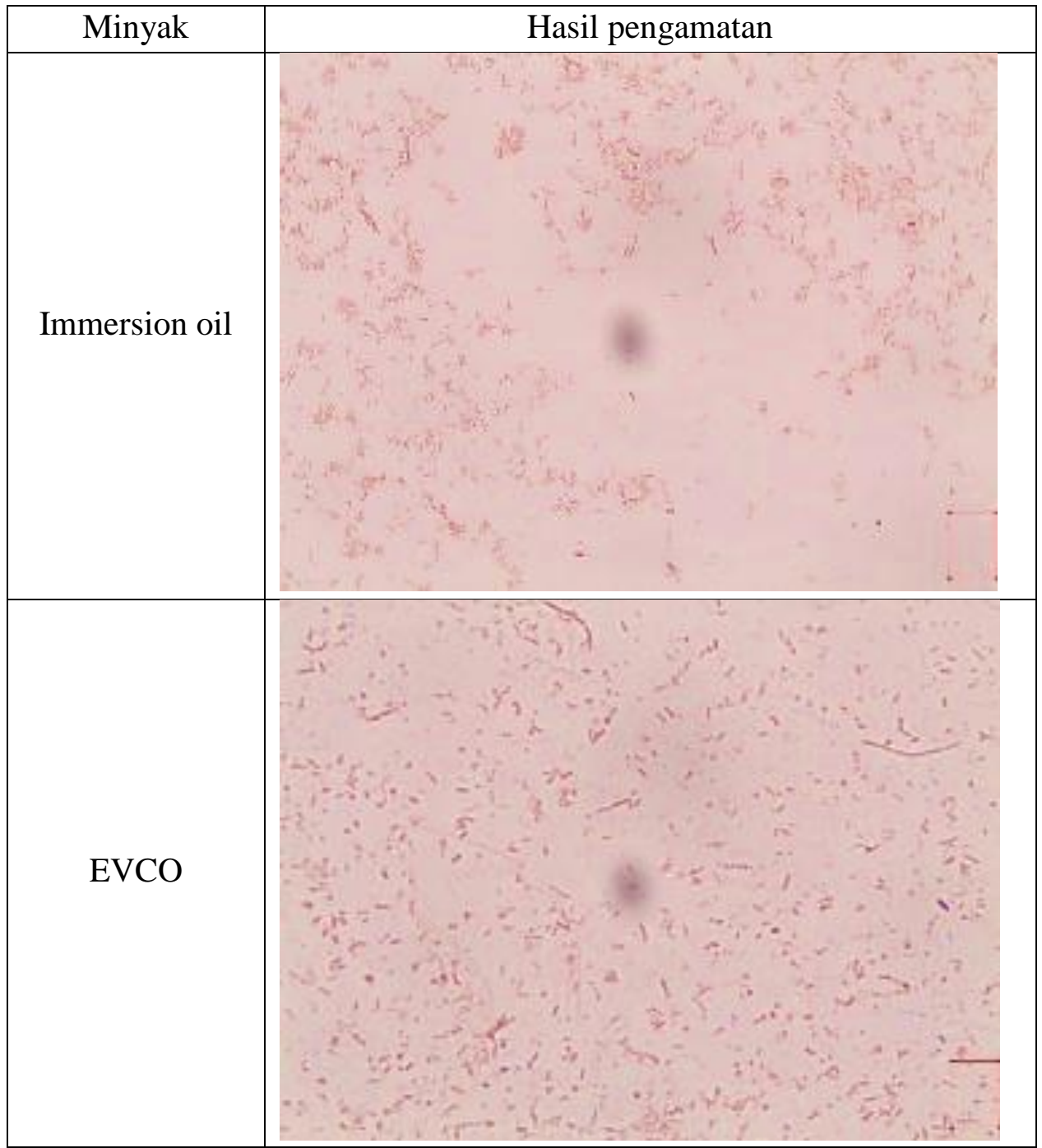


Maharani RI, Mustikaningtyas D, Widyaningrum K : Vegetable Oil Sebagai Alternatif Pengganti Immersion Oil

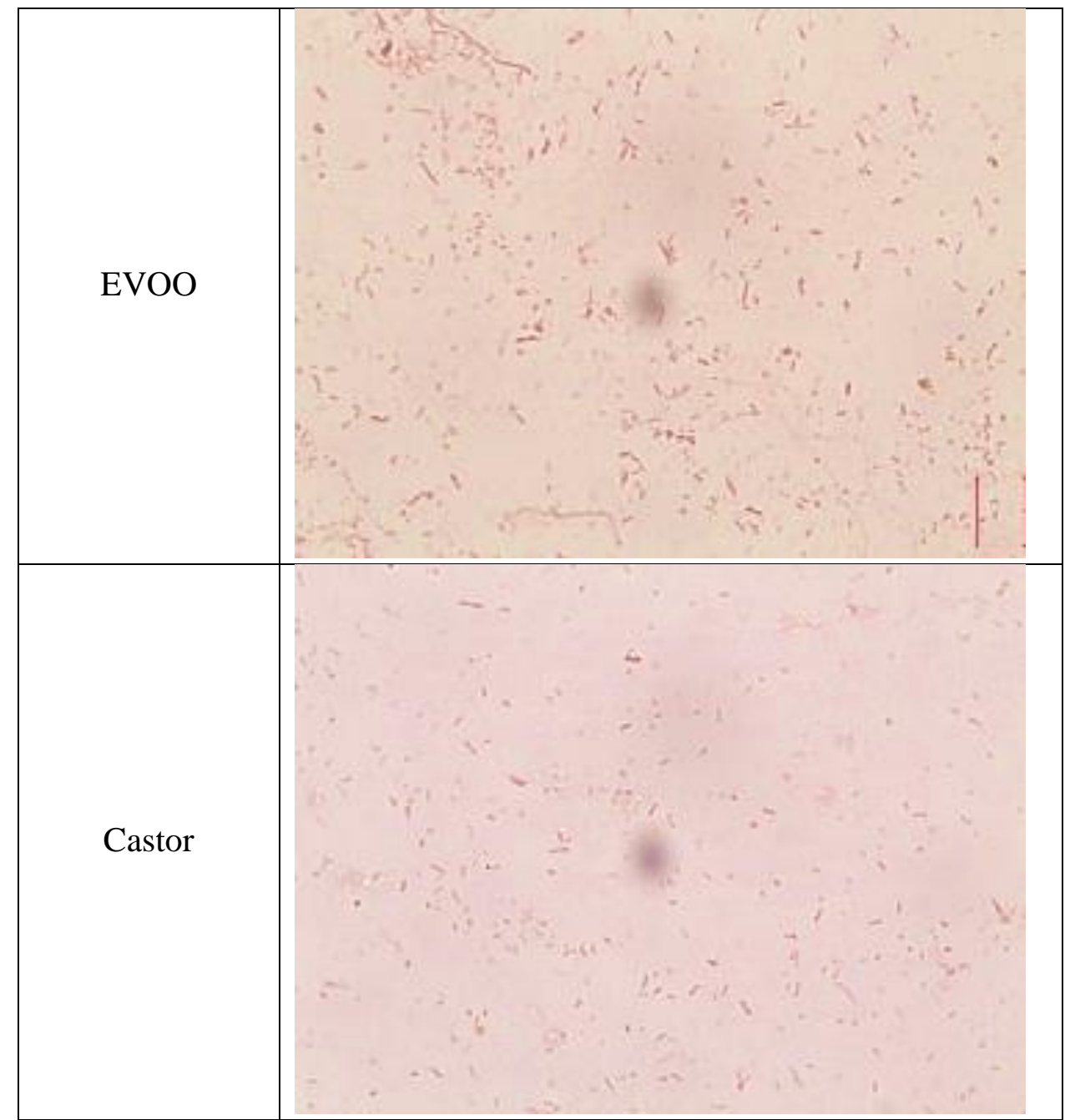

Data untuk hasil pengamatan terhadap katajaman dan kotras hasil pengamatan dilakukan untuk keempat perlakukan diambil dari kuisioner yang diberikan kepada tim peneliti dan mahsiswa yang telah mendapatkan mata praktikum mikrobiologi. Setelah dilakukan pengujian stastistik normalitas terhadap ketajaman dan kontras gambar yang dihasilkan terhadap keempat minyak didapat hasil seperti dalam tabel 2. Hasilnya yang diperoleh menunjukkan nilainya sig < 0,05 maka dilanjutkan menggunakan uji non parametrik kruskal wallis test spss.

Tabel 2. Hasil test normalitas ketajaman dan kontras gambar

\begin{tabular}{|c|c|c|c|c|c|c|c|}
\hline & \multirow[t]{2}{*}{ Minyak } & \multicolumn{3}{|c|}{ Kolmogorov-Smirnova } & \multicolumn{3}{|c|}{ Shapiro-Wilk } \\
\hline & & Statistic & $\mathrm{df}$ & Sig. & Statistic & df & Sig. \\
\hline \multirow[t]{4}{*}{ Ketajaman } & IMO & .245 & 10 & .091 & .820 & 10 & .025 \\
\hline & EVCO & .324 & 10 & .004 & .794 & 10 & .012 \\
\hline & Evoo & .272 & 10 & .035 & .802 & 10 & .015 \\
\hline & Castor & .305 & 10 & .009 & .781 & 10 & .008 \\
\hline \multirow[t]{4}{*}{ Kontras } & IMO & .245 & 10 & .091 & .820 & 10 & .025 \\
\hline & EVCO & .324 & 10 & .004 & .794 & 10 & .012 \\
\hline & EVoo & .272 & 10 & .035 & .802 & 10 & .015 \\
\hline & Castor & .305 & 10 & .009 & .781 & 10 & .008 \\
\hline
\end{tabular}

a. Lilliefors Significance Correction 
Dengan hasil test statistik kruskal-wallis dengan nilai asymp.sig 0,888 > 0,05 (tabel 3), hal ini menunjukan bahwa tidak ada perbedaan antara pengunaan keempat perlakukan pada preparat preparat bakteri pada saat dilakukan pengamatan di bawah mikroskop. Sehingga penggunaan vegetable oil dapat sebagai alternatif pengganti immersion oil. Penelitian terdahulu menyebutkan tidak ada pebedaan signifikan hasil gambar yang dihasilkan antara penggunaan coconut oil dengan immersion oil pada pengamatan mikroskopis (Balba et.al, 2018). Tanaman penghasil minyak ini merupakan tanaman endemik di negara-negara tropis dan memiliki nilai lebih murah dibandingkan dengan minyak imersi sintetis (Adeniyi et.al, 2015). Minyak ini tidak terfraksi sehingga dapat disimpan pada suhu kamar dalam jangka waktu tidak terbatas dalam bentuk cair. Hal inilah yang menyebabkan minyak ini cocok untuk digunakan di laboratorium (Wallace, 2017). Olive oil ini juga telah terbukti sebagai bahan alternatif ramah lingkungan (Sugunakar et.al, 2015).

Tabel 3. Hasil test kruskal wallis ketajaman dan kontras gambar

Test Statistics ${ }^{\mathrm{a}, \mathrm{b}}$

\begin{tabular}{|l|r|r|}
\hline & Ketajaman & Kontras \\
\hline Chi-square & .637 & .637 \\
df & 3 & 3 \\
Asymp. Sig. & .888 & .888 \\
\hline
\end{tabular}

a. Kruskal Wallis Test

\section{b. Grouping Variable: Minyak}

Dalam penggunaan minyak saat pengamatan harus diperhatikan pula peralatan laboratorium yang telah dipakai, dalam hal ini adalah mikroskop. Setelah pemakaian immersion oil perlu dilakukan pembersihan lensa obyektif yang terendam minyak, biasanya menggunakan xylol sebagai agen pembersih. Dengan begitu akan menambah biaya dan meningkatkan resiko penggunaan bahan kimia. Sedangkan untuk penggunaan vegetable oil hanya menggunakan tissue lensa sudah bisa terhapus. Perbandingan saat dilakukan pembersihan dengan menggunakan tissue lensa dapat dilihat pada gambar 2.

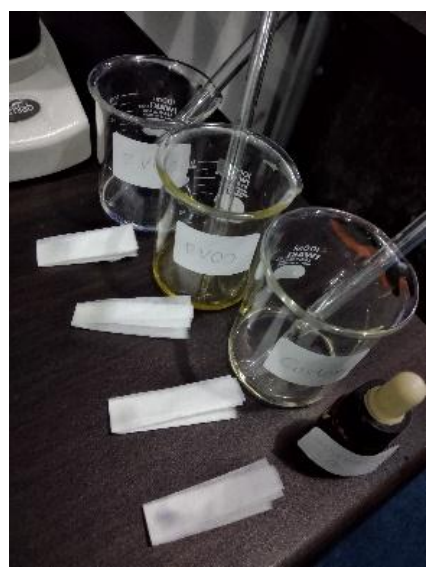

Gambar 2. Tissue lensa untuk membersihkan minyak di lensa obyektif mikroskop 
Maharani RI, Mustikaningtyas D, Widyaningrum K : Vegetable Oil Sebagai Alternatif Pengganti Immersion Oil

\section{KESIMPULAN}

Hasil yang diperoleh menunjukan vegetable oil dapat digunakan sebagai penganti immersion oil. Dengan hasil uji statistik menunjukkan hasil 0,888 diatas standar penentu perbedaan signifikan 0,05 , sehingga dinyatakan bahwa tidak ada perbedaan secara signifikan terhadap keempat perlakukan yang diberikan.

\section{DAFTAR PUSTAKA}

Adeniyi, I.M., Adejoba, O.R., Akinlabi F.M., Alao, O.J. (2015). Vegetable Oils as Clearing Agents. Achievements in the Life Sciences, 10, Retrieved Februari 11, 2020 from http://doi.org/10.1016/j.als.2016.05.001

Balba, Dolce Monica U., Karla Anika A. Quiobe, Casey Lyn Z. Valbuena. (2018). Coconut oil as an alternative for immersion oil. LPU- Laguna Journal of allied medicine Vol. 3 No. 1 August 2018

Cargille, J. J. (2008). Immersion oil and the microscope from http://www.cargille.com/ immersionoilmicroscope.shtml

Christophe-J. Le Coz, Dagmar Coninx, Annik Van Rengen, Suzane El Aboubi, Georges Ducombs, Marie-Hélène Benz, Sylvie Boursier, Martine Avenel-Audran, Jean-Luc Verret. (2017). An epidemic of occupational contact dermatitis from an immersion oil for microscopy in laboratory personnel. Contact Dermatitis: Volume 40, Issue 2. https://doi.org/10.1111/j.1600-0536.1999.tb05995.x

Davidson, Michael W. (2017). Introduction to microscope objectives. Retrieved February11, 2020 from https://www.microscopyu.com/

GE Healthcare Bio-Sciences Corp. (2017). DeltaVision ${ }^{\mathrm{TM}}$ OMX V4/SR : Immersion Oil Optimization. Retrieved Juni 23, 2020 from www.gelifesciences.com

International Gem Society. (2017). Refractive index of common household liquids. Retrieved November 2017, from https://www.gemsociety.org/

Maharani, R.I, Sriyadi, dan F.A. Sasi. (2019). STAFAN modifikasi alat staining tray dalam perwanaan bakteri. Prosiding Seminar Nasional IV Hasil Penelitian PLPI, 20 September 2019. Vol IV-ISSN: 2548-1924

Sacher, R. (2000). Microscope Immersion Oil. Volume 8, Issue 8, October 2000, pp. 33-35. DOI: https://doi.org/10.1017/S1551929500060442. Published online by Cambridge University Press: 14 March 2018

U.S. National Library Of Medicine. (2020). Compound Summary: Benzyl Benzoate. Retrieved Februari 28, 2020 from https://Pubchem.Ncbi.Nlm.Nih.Gov/ Compound /Benzyl-Benzoate

Victor R, Jayalakshamma, Rajangam Ssayee. (2005). Cost effective, qualitative immersion oil for microscopy. J.Anat.Soc. India 54 (2) 1-9. http://medind.nic.in/jae/t05/ i2/jaet05i2p48.pdf

Wallace. (2017). How Do I Store Coconut Oil? Retrieved from https://www.livestrong.com/ Wilson, M. (2017). Immersion Objectives: Using Oil, Glycerol, or Water to Overcome some of the Limits of Resolution. Article: August 09, 2017. https://www.leicamicrosystems.com/science-lab/immersion-objectives-using-oil-glycerol-or-water-toovercome-some-of-the-limits-of-resolution.

\begin{tabular}{|l|l|l|l|}
\hline Accepted Date & Revised Date & Decided Date & Accepted to Publish \\
\hline 21 Juli 2020 & 30 Juli 2020 & 04 Agustus 2020 & Ya \\
\hline
\end{tabular}

